\title{
The effect of heat treatment on mechanical properties of pulsed Nd:YAG
}

\author{
welded thin Ti6Al4V
}

\author{
Y. Fan ${ }^{1,2, a}$, P.H. Shipway, ${ }^{2, b}$, G.D. Tansley ${ }^{3, c}$, J. $X u^{1, d}$ \\ ${ }^{1}$ School of Material Science and Engineering, China University Mining and Technology, Xuzhou, \\ Jiangsu, 221008, China \\ ${ }^{2}$ Division of Materials, Mechanics and Structures, The Faculty of Engineering, University of \\ Nottingham, University Park, Nottingham, NG7 2RD, UK \\ ${ }^{3}$ Engineering Systems \& Management, Aston Triangle, Aston University, Birmingham, B4 7ET, UK \\ a fanyu2002@hotmail.com, ${ }^{\mathrm{b}}$ Philip.shipway@nottingham.ac.uk, ${ }^{\mathrm{C}}$ G.D.Tansley@aston.ac.uk, ${ }^{\mathrm{d}}$ \\ jiexu.ustb@gmail.com
}

Keywords: Pulsed Nd:YAG Laser Welding, Ti6Al4V, Thin, Heat treatment

\begin{abstract}
Pulsed Nd:YAG has been adopted successfully in welding process of thin $(0.7 \mathrm{~mm})$ Ti6Al4V. Laser welding of such thin sheet requires a small focal spot, good laser beam quality and fast travel speed, since too much heat generation can cause distortion for thin sheet weld. The microstructures of Ti6Al4V were complex and strongly affected the mechanical properties. These structures include: $\alpha^{\prime}$ martensite, metastable $\beta$, Widmanstätten, bimodal, lamellar and equiaxed microstructure. Bimodal and Widmanstätten structures exhibit a good-balance between strength and ductility. The microstructure of pulsed Nd:YAG welded Ti6A14V was primarily $\alpha^{\prime}$ martensite, which showed the lowest ductility but not significantly high strength. A heat treatment at $950^{\circ} \mathrm{C}$ followed by furnace cooling can transform the microstructure in the weld from $\alpha^{\prime}$ martensite structure into Widmanstätten structure.
\end{abstract}

\section{Introduction}

The material of thin Ti6Al4V alloy sheet is widely used in both the aerospace industries and medical device industry for its high stiffness and strength to weight ratios, high corrosion resistance, biocompatibility and relative ease of processing [1-3]. As one type of solid state laser beam welding, $\mathrm{Nd}$ :YAG welding has been widely adopted for welding of very thin sections [4]. To summarize a body of previous research [4-7], the microstructures of Nd:YAG welded zone of Ti6Al4V are always martensite $\alpha^{\prime}$. The weld zone in laser beam welding is melted and resolided metal resulting from a process lasting only a short period of time. Hence the Nd:YAG welded zone has properties similar to those resulting from a water quench process from a high temperature. The mechanical properties of martensite $\alpha^{\prime}$ is generally seen as poor since the titanium martensite is not significantly stronger than the parent phase [4]. Previous researchers have indicated that the mechanical properties (strength and toughness) of Ti6Al4V alloy are quite sensitive to microstructure $[3,8,9]$. The microstructure of titanium alloys are generally described by the size and arrangement of the $\alpha$ and $\beta$ phases. The microstructures are controlled by heat treatment generally at temperatures in the dual $\alpha-\beta$ phase region $[10,11]$. Besides the martensite $\alpha^{\prime}$, the other types of structure in Ti6Al4V have been indicated by previous researchers, which include equiaxed microstructure, lamellar 
microstructure, bimodal microstructure, Widmanstätten structure, metastable $\beta$ structure. There are very few reports in the literature on Nd:YAG welded Ti6Al4V. Thus, the effect of heat treatment on mechanical properties of Nd:YAG welded Ti6A14V were studied.

\section{Experimental Procedures}

The material used in this study was $0.7 \mathrm{~mm}$ thick sheet of Ti6Al4V alloy. Welding of the Ti6Al4V sheet was made in butt-joint mode. The Nd:YAG lasers were A JK702H GSI pulsed Nd:YAG laser with $400 \mu \mathrm{m}$ fibre beam delivery laser was used for the pulsed laser welding trials. The conditions selected for further welding trials are shown in Table 1.

Table 1 Main parameters adopted in Pulsed Nd:YAG welding process

\begin{tabular}{|c|c|c|c|c|c|}
\hline Energy / J & $\begin{array}{c}\text { Pulse width } \\
\text { / } \mathbf{~ m s}\end{array}$ & $\begin{array}{c}\text { Peak power } \\
\text { / W }\end{array}$ & $\begin{array}{c}\text { Feed rate / } \\
\text { mmmin }^{-1}\end{array}$ & $\begin{array}{c}\text { Pulse rate } \\
\text { / Hz }\end{array}$ & $\begin{array}{c}\text { Spot size / } \\
\text { um }\end{array}$ \\
\hline 2.9 & 7 & 414 & 360 & 20 & 300 \\
\hline
\end{tabular}

Micro-hardness of the samples was measured using the Vickers Hardness testing with a Leco M-400 tester ${ }^{1}$, using a 15 seconds indentation time. The tensile test experiments were carried out on Instron 5569 Tensile and Compression Test Machine ${ }^{2}$ at room temperature with a load cell of 50 $\mathrm{kN}$ and a cross head speed of $1 \mathrm{~mm} \mathrm{~min}^{-1}$, with tests being carried out to tensile failure. All the tensile test coupons (Fig.1) were machined using a vertical milling cutter from parent material and weld samples.

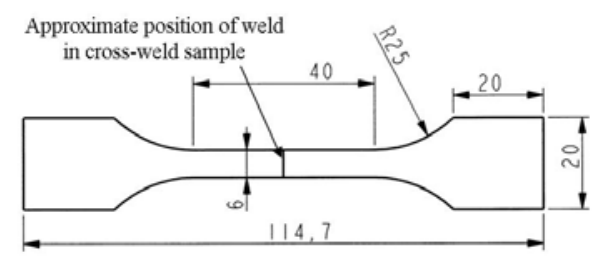

Fig. 1 Geometry of tensile test sample

\section{Results and discussion}

\section{Mechanical properties of parent material}

The main mechanical properties of the PM are shown in Table 2 which includes microhardness, Young's modulus, $0.2 \%$ tensile stress and elongation to fatigue. There is no significant difference between the hardness value for both cross section and top surface.

Table 2 Mechanical properties of parent material as-received Ti6Al4V

\begin{tabular}{|c|c|c|c|c|c|}
\hline $\begin{array}{c}\text { Hardness } \\
\text { (Cross section) } \\
/ \mathbf{~ k g m m}^{-2}\end{array}$ & $\begin{array}{c}\text { Hardness } \\
\text { (Top surface) } \\
/ \mathbf{~ k g m m}^{-2}\end{array}$ & $\begin{array}{c}\text { Young's } \\
\text { Modulus / } \\
\text { GPa }\end{array}$ & $\begin{array}{c}\mathbf{0 . 2 \%} \text { Tensile } \\
\text { stress / MPa }\end{array}$ & $\begin{array}{c}\text { Maximu } \\
\mathbf{m} \text { stress / } \\
\mathbf{M P a}\end{array}$ & $\begin{array}{c}\text { Elongatio } \\
\mathbf{n} / \mathbf{\%}\end{array}$ \\
\hline $362.5 \pm 5.3$ & $367.4 \pm 6.9$ & $111.0 \pm 3.1$ & $978.2 \pm 15.3$ & $1054 \pm 4.3$ & $13.6 \pm 1.7$ \\
\hline
\end{tabular}

*the error bar $( \pm)$ is standard deviation

The Ti6Al4V parent material was heat treated at $650^{\circ} \mathrm{C}, 750^{\circ} \mathrm{C}, 850^{\circ} \mathrm{C}, 950^{\circ} \mathrm{C}$ and $1050^{\circ} \mathrm{C}$ for 1 hours followed by furnace-cooling (A) or water-quenching (Q) to investigate the microstructural development. The optical images of PM with different heat treatment temperatures and cooling rates are shown in Fig. 2. There is no significant difference from PM to 650A (Fig. 2b), 750A (Fig.

\footnotetext{
${ }^{1}$ Leco® Corporation, 3000 Lakeview Ave. St. Joseph, MI 49085-2396, USA

2 Instron, Coronation Road, High Wycombe, Bucks, HP12 3SY, UK
} 
2d), 850A (Fig. 2f), 650Q (Fig. 2c), 750Q (Fig. 2e). All of these images exhibit equiaxed $\alpha$ phase surrounded by $\beta$ phase boundary. There is a slight difference between 850Q (Fig. 2g) and others, where the $\beta$ phase boundary seems to be thicker. In Fig.2h (PM heat treated at 950A), an equiaxed structure with primary $\alpha$ phase and part of $\beta$ phase boundary still exists, but some transformation from prior $\beta$ phase boundary to lamellar $\alpha+\beta$ phase has occurred. In Fig.2i (PM heat treated at 950Q), an equiaxed structure with primary $\alpha$ phase and part of $\beta$ phase boundary is observed which is as similar as 950A. The difference is that there is no lamellar $\alpha+\beta$ phase but instead a region of metastable $\beta$ (dark region) which has been transformed from the $\beta$ phase boundary regions is observed. Fig. $2 \mathrm{j}$ shows a typical Widmanstätten structure with $\alpha$ grain boundary in the prior $\beta$ grains from $1050^{\circ} \mathrm{C}$ furnace cooling. Fig. $2 \mathrm{k}$ shows acicular $\alpha^{\prime}$ martensite structure with $\beta$ phase between martensitic laths. The grain size tends to be coarse.

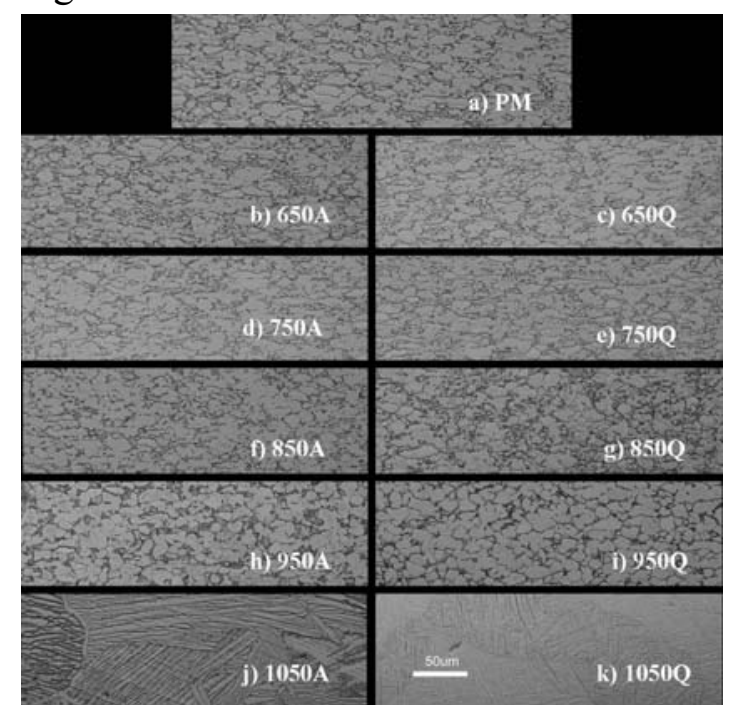

Fig.2 Optical microstructure of as-received and heat-treatment Ti6Al4V. The number indicates the heat treatment temperature. $A$ indicates furnace cool and $Q$ indicates a quench.

Hardness testing has been conducted on heat treated Ti6A14V PM. Table 3 shows the results of hardness examination of Ti6Al4V heat treated at $650^{\circ} \mathrm{C}, 750^{\circ} \mathrm{C}, 850^{\circ} \mathrm{C}, 950^{\circ} \mathrm{C}$ and $1050^{\circ} \mathrm{C}$ for 1 hour with furnace-cooling (A) and water-quenching (Q) respectively. There is no significant change of hardness values between 650A, 750A, 850A, 650Q and 750Q. Following furnace-cooling, hardness values increase from $850^{\circ} \mathrm{C}$ to $1050^{\circ} \mathrm{C}$; the highest hardness value appeared at $1050^{\circ} \mathrm{C}$ (7.41\% bigger than $\mathrm{PM}$ ). Following water-quenching, hardness values increased from somewhere between $750^{\circ} \mathrm{C}$ and $850^{\circ} \mathrm{C}$ to $1050^{\circ} \mathrm{C}$; the highest hardness value is $15.58 \%$ bigger than that of PM.

Table 3 Hardness data of heat treated Ti6Al4V

\begin{tabular}{|c|c|c|c|c|c|}
\hline${\text { Unit: } \text { kgmm }^{-2}}^{-2} \mathbf{6 5 0 A}$ & $\mathbf{7 5 0 A}$ & $\mathbf{8 5 0 A}$ & $\mathbf{9 5 0 A}$ & $\mathbf{1 0 5 0 A}$ \\
\hline Furnace cool & $361.0 \pm 3.4$ & $360.0 \pm 2.0$ & $365.2 \pm 2.3$ & $378.2 \pm 4.1$ & $389.4 \pm 5.9$ \\
\hline PM $(362.53 \pm 5.32)$ & $-0.42 \%$ & $-0.70 \%$ & $0.07 \%$ & $4.32 \%$ & $7.41 \%$ \\
\hline \multicolumn{7}{|l}{} \\
\hline Unit: kgmm $^{-2}$ & $\mathbf{6 5 0 Q}$ & $\mathbf{7 5 0 Q}$ & $\mathbf{8 5 0 Q}$ & $\mathbf{9 5 0 Q}$ & $\mathbf{1 0 5 0 Q}$ \\
\hline Water quench & $361.6 \pm 3.3$ & $362.0 \pm 2.0$ & $370.8 \pm 3.4$ & $394.6 \pm 4.8$ & $419.0 \pm 9.1$ \\
\hline PM (362.53 \pm 5.32$)$ & $-0.26 \%$ & $-0.15 \%$ & $2.28 \%$ & $8.85 \%$ & $15.58 \%$ \\
\hline
\end{tabular}

*the error bar $( \pm)$ is standard deviation

The trend of $0.2 \%$ proof stress values of heat treated Ti6Al4V following both furnace-cooling and water-quenching is very similar to that of the hardness values. The highest proof stress values appeared at $1050^{\circ} \mathrm{C}$ water-quenching condition, which is $13.78 \%$ higher than that of the PM. The data are shown in Table 4. 
Table $40.2 \%$ proof tensile stress of heat treatment on Ti6Al4V

\begin{tabular}{|c|c|c|c|c|c|}
\hline Unit: MPa & 650A & 750A & 850A & 950A & 1050A \\
\hline Furnace cool & $980.7 \pm 22.1$ & $979.7 \pm 11.5$ & $987.0 \pm 15.5$ & $1017.3 \pm 22.1$ & $1041.0 \pm 32.0$ \\
\hline PM (978.20) & $0.25 \%$ & $0.15 \%$ & $0.90 \%$ & $4.00 \%$ & $6.42 \%$ \\
\hline \multicolumn{7}{|l}{} \\
\hline Unit: MPa & $\mathbf{6 5 0 Q}$ & $\mathbf{7 5 0 Q}$ & $\mathbf{8 5 0 Q}$ & $\mathbf{9 5 0 Q}$ & $\mathbf{1 0 5 0 Q}$ \\
\hline Water quench & $981.3 \pm 14.5$ & $981.0 \pm 22.0$ & $1008.3 \pm 13.1$ & $1052.0 \pm 28.5$ & $1113.7 \pm 31.5$ \\
\hline PM (978.20) & $0.32 \%$ & $0.28 \%$ & $3.08 \%$ & $7.54 \%$ & $13.78 \%$ \\
\hline
\end{tabular}

*the error bar $( \pm)$ is standard deviation

The value of elongation to failure of $\mathrm{PM}$ cannot be improved by furnace-cooling or water-quenching following heat treatment in the temperature range $650^{\circ} \mathrm{C}$ to $1050^{\circ} \mathrm{C}$ here is no significant change of elongation values between 650A, 750A, 850A, 650Q and 750Q. In annealing furnace-cooling condition, elongation values decrease from $850^{\circ} \mathrm{C}$ till $1050^{\circ} \mathrm{C}$; the lowest elongation value is $24.38 \%$ smaller than that of the PM. In the water-quenched condition, elongation values drop off more quickly from somewhere between $750^{\circ} \mathrm{C}$ and $850^{\circ} \mathrm{C}$ till $1050^{\circ} \mathrm{C}$. The lowest elongation value is $42.73 \%$ smaller than that of PM. The data are presented in Table 5 .

Table 5 Percentage elongation as a function of heat treatment schedule for Ti6Al4V

\begin{tabular}{|c|c|c|c|c|c|}
\hline Unit: \% & $\mathbf{6 5 0 A}$ & $\mathbf{7 5 0 A}$ & $\mathbf{8 5 0 A}$ & 950A & 1050A \\
\hline Furnace cool & $13.6 \pm 1.1$ & $13.9 \pm 0.4$ & $13.5 \pm 1.0$ & $11.8 \pm 0.4$ & $10.3 \pm 0.6$ \\
\hline PM (13.62) & $-0.15 \%$ & $2.06 \%$ & $0.88 \%$ & $-13.61 \%$ & $-24.38 \%$ \\
\hline \multicolumn{5}{|c|}{} \\
\hline Unit: \% & $\mathbf{6 5 0 Q}$ & $\mathbf{7 5 0 Q}$ & $\mathbf{8 5 0 Q}$ & $\mathbf{9 5 0 Q}$ & $\mathbf{1 0 5 0 Q}$ \\
\hline Water quench & $13.5 \pm 0.7$ & $13.7 \pm 0.2$ & $11.7 \pm 0.5$ & $9.9 \pm 0.2$ & $7.8 \pm 0.5$ \\
\hline PM (13.62) & $-0.63 \%$ & $0.58 \%$ & $-13.85 \%$ & $-27.31 \%$ & $-42.73 \%$ \\
\hline
\end{tabular}

*the error bar $( \pm)$ is standard deviation

\section{Microstructures of Nd:YAG welded Ti6Al4V}

The microstructures of a Nd:YAG welded Ti6A14V are shown in Fig.3. The weldment of Nd:YAG welded Ti6Al4V shows the top surface width of the molten zone $(0.94 \mathrm{~mm})$ is nearly twice the size of that of the bottom surface $(0.5 \mathrm{~mm})$. The enlarged microstructure (Fig.3 (a)) shows the $\alpha^{\prime}$ martensite structure and $\beta$ phase between martensitic laths inside of the grains in FZ. The boundary of FZ/HAZ is obvious. The microstructure of HAZ in Fig.3b and boundary of HAZ/PM Fig.3c include a mixture of martensite $\alpha^{\prime}$, acicular $\alpha$, and primary $\alpha$.

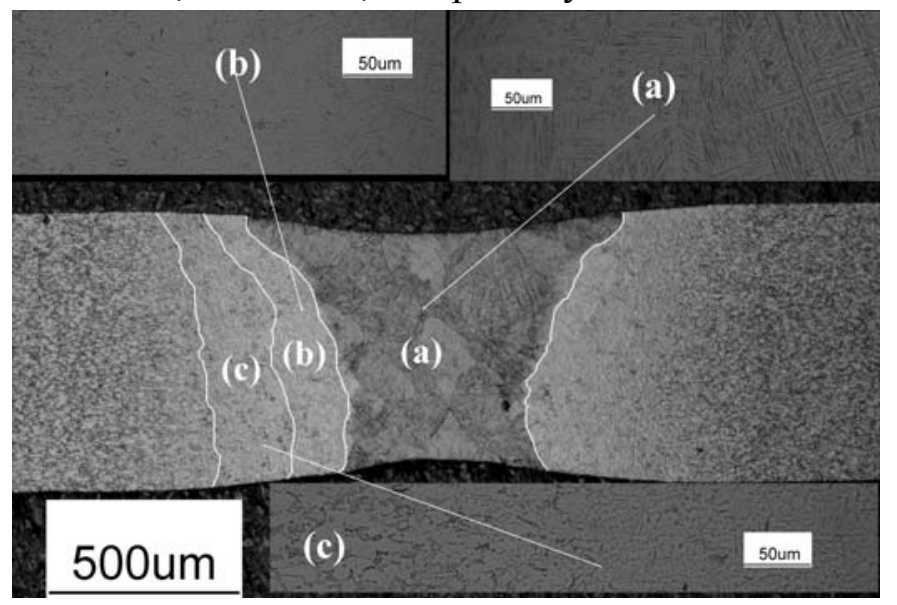

Fig.3 Microstructure of Nd:YAG welded Ti6Al4V (a) Microstructure of the FZ (b) Microstructure of the HAZ (c) Microstructure of boundary of the HAZ/PM

In the Nd:YAG, welded Ti6Al4V (Fig.4), hardness values increase when proceeding from the 
PM across the HAZ towards the FZ. Table 6 shows the mean values found in the FZ, HAZ and PM for Nd:YAG welds. It listed the percentage increase from $\Delta \%$ FZ-PM and $\Delta \%$ HAZ-PM. It can be noted that the increase $\Delta \%$ FZ-PM is much larger than $\Delta \%$ HAZ-PM.

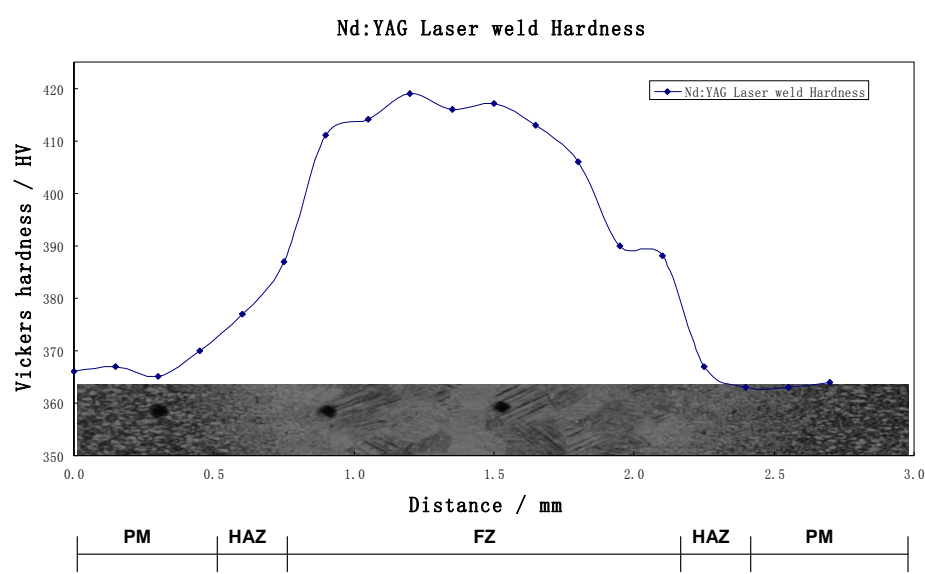

Fig.4 Hardness trend across Nd:YAG Ti6Al4V with micrograph indicating position in the weld structures

Table 6 Hardness mean values obtained for different LWB in Ti6Al4V

\begin{tabular}{|c|c|c|c|c|c|}
\hline & FZ & HAZ & PM & $\Delta$ \%FZ-PM & $\Delta$ \%HAZ-PM \\
\hline Nd:YAG & $414.2 \pm 7.4$ & $386.9 \pm 6.2$ & $366.5 \pm 7.1$ & 12 & 5 \\
\hline
\end{tabular}

\section{Characterisation of heat treatment on Nd:YAG welded Ti6Al4V}

Fig.5 shows the cross-sectional microstructures of $\mathrm{Nd}$ :YAG welded Ti6Al4V samples which are heat treated at $650^{\circ} \mathrm{C}, 750^{\circ} \mathrm{C}, 850^{\circ} \mathrm{C}, 950^{\circ} \mathrm{C}$ and $1050^{\circ} \mathrm{C}$ for 1 hour with furnace cooling. The microstructure of FZ in 650A and 750A is still martensite $\alpha^{\prime}$. Table 7 indicates hardness values of these two heat treatment conditions are very similar to that of Nd:YAG welded Ti6Al4V without heat treatment. From $850 \mathrm{~A}$ to $1050 \mathrm{~A}$, martensite $\alpha^{\prime}$ starts to transform into $\alpha$ colony microstructure with $\beta$ phase boundary. As the temperature increases, the width of $\alpha$ colony becomes thicker. From $950 \mathrm{~A}$ to $1050 \mathrm{~A}, \alpha$ grain boundary in the prior $\beta$ grain starts to appear. In $1050 \mathrm{~A}, \alpha$ grain boundary tends to be very coarse; and the PM transforms into lamellar structure with plenty of oriented $\alpha$ colonies and $\beta$ phase boundaries. The hardness values slightly drop off from 950A to 1050A (Table 7).

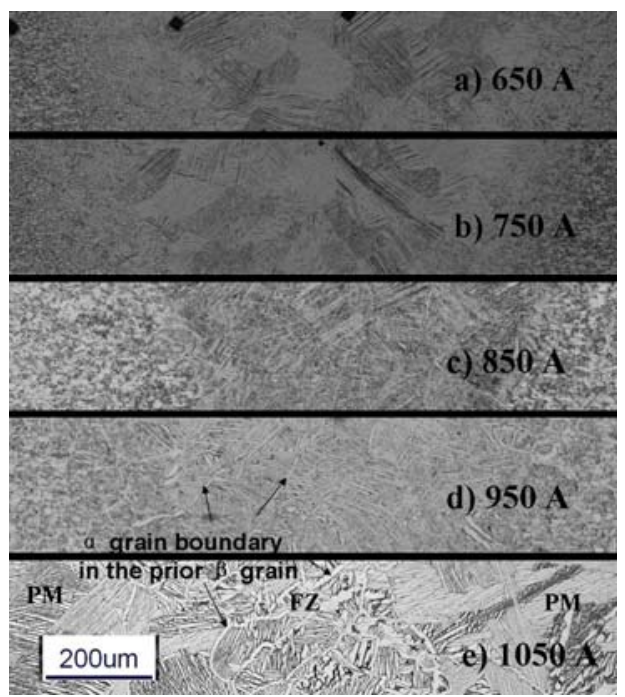

Fig.5 Microstructures of Nd:YAG welded Ti6Al4V heat treated at a range of temperatures for 1 hour following by furnace cooling

Table 7 Hardness data from the FZ of Nd:YAG welded Ti6Al4V following heat treatment of a 
range of temperatures followed by furnace cooling for 1 hour

\begin{tabular}{|c|c|c|c|c|c|}
\hline Unit: $^{\mathbf{k g m m}^{-2}}$ & 650A & 750A & 850A & 950A & 1050A \\
\hline Furnace cool & $416.0 \pm 6.4$ & $413.3 \pm 9.0$ & $408.1 \pm 8.6$ & $404.2 \pm 7.1$ & $403.2 \pm 6.6$ \\
\hline Nd:YAG (414.2 \pm 7.4$)$ & $0.48 \%$ & $-0.24 \%$ & $-1.45 \%$ & $-2.42 \%$ & $-2.66 \%$ \\
\hline
\end{tabular}

\section{Conclusions}

The rank of the strength from high to low for all types of the microstructures of Ti6Al4V observed in this study is: $\alpha^{\prime}$ martensite, metastable $\beta$, Widmanstätten, bimodal and equiaxed microstructure. The rank of the ductility from high to low for all types the microstructures of Ti6Al4V observed in this study is: equiaxed, bimodal, Widmanstätten, metastable $\beta$ and $\alpha^{\prime}$ martensite microstructure.

The microstructures transformed from different PMs by heat treatment depend strongly on the original PM microstructures. The structure with the best combination of mechanical properties is a bimodal structure which can be formed from the PM following $950^{\circ} \mathrm{C}$ heat treatment with a furnace cool. A heat treatment temperature of $950^{\circ} \mathrm{C}$ was used to modify the martensite structure in $\mathrm{FZ}$ of laser welded Ti6A14V; the transformed structures are thought be Widmanstätten structures.

\section{References}

[1] I.J. Polmear: Light Alloys, from traditional alloy to nanocrystals, 4th edn, (2006), Butterworth-Heinemann.

[2] L.W. Tsay and C.Y. Tsay: The effect of microstructures on the fatigue crack growth in Ti6Al4V laser welds, Int. J. Fatigue, (1997), 19 (10), 713-720.

[3] F.J. Gil, M.P Ginebra, J.M. Manero and J.A. Planell: Formation of $\alpha$-Widmanstätten structure: effect of grain size and cooling rate on the Widmanstätten morphologies and on the mechanical properties in Ti6Al4V alloy, Journal of Alloy and compounds, (2001), 329, 142-152.

[4] American Welding Society: Recommended Practices for Laser Beam Welding, Cutting, and Drilling, (1998), AWS/ANSI

[5] T.Y. Kuo and S.L. Jeng: Porosity reduction in Nd:YAG laser welding of stainless steel and inconel alloy by using a pulsed wave, Journal of physics D: applied physics, (2005), 38, $722-728$.

[6] S. E. Anthony: 'Lasers'. Mill Valley, (1986), CA University, Science books.

[7] Y. Kawahito, M. Kito and S. Katayama: In-process monitoring and adaptive control for gap in micro butt welding with pulsed YAG laser, Journal of Physics D: Applied Physics, (2007), 40, 2972-2978.

[8] M.Žitňanskŷ and L.Čaplovič: Effect of the thermomechanical treatment on the structure of titanium alloy Ti6A14V. Journal of Materials Processing Technology. (2004); 157-158:643-9

[9] M.T.Jovanović, S.Tadić, S.Zec, Z.Mišković and I.Bobić: The effect of annealing temperatures and cooling rates on microstructure and mechanical properties of investment cast Ti-6Al-4V alloy. Materials and design. (2006); 27:192-9

[10]D.Hardie and S.Ouyang: Effect of microstructure and heat treatment on fracture behaviour of smooth and precracked tensile specimens of Ti6Al4V. Materials Science and Technology. (1999); 15:1049-57.

[11]S.Shademan, V.Sinha, A.B.O.Soboyejo and W.O.Soboyejo: An investigation of effects of microstructure and stress ratio on fatigue crack growth in Ti-6Al-4V with colony $\alpha / \beta$ microstructures. Mechanics of materials. (2003); 36:161-75. 